\title{
A quantitative approach for conservation of endangered and endemic plants from Kosovo, SE Europe
}

\author{
Naim Berisha ${ }^{1}$, Elez Krasniqi ${ }^{1 *}$, Fadil Millaku ${ }^{1,2}$ \\ ${ }^{1}$ Faculty of Natural Sciences and Mathematics, University of Prishtina, Str. "George Bush", 31, 10000 , \\ Prishtina, Republic of Kosovo \\ ${ }^{2}$ Faculty of Agribusiness, University "Haxhi Zeka", Str. "UÇK”, 30 000, Peja, Republic of Kosovo
}

\begin{abstract}
Berisha, N., Krasniqi, E., Millaku, F., 2020. A quantitative approach for conservation of endangered and endemic plants from Kosovo, SE Europe. Folia Oecologica, 47 (1): 52-63.

Basic patterns of most priority biodiversity areas of Kosovo that shall be considered for conservation studies are offered here. On this work, all plant taxa that are included in the Kosovarian Red list are analysed and their analogy is interpreted to conservation priority hotspots. Kosovo represents an important centre for Balkan biodiversity; therefore a quantitative evaluation of the importance of different priority areas for conserving plant diversity of Kosovo is very much needed. This study provides a detailed quantitative approach concerning the identification of priority areas for biodiversity conservation, using threatened and endangered plant taxa in well-known grid squares system. Used grid squares $(20 \times 20 \mathrm{~km})$ were classified into four different groups in terms of their conservation importance. Valuation factors taken into account are IUCN based risk category, endemism as well as ecological and distributional attributes. The results indicated that there are four grid squares - D4 (0.4300), G7 (0.3910), G8 (0.2750) and E4 (0.2860), that have remarkable conservation importance. These grid squares are all located along mostly high-elevation areas of two National Parks in Kosovo. These national scale data should prove to be very appropriate and easy to follow evidence for environmental decision-making bodies as well as be used for further research.
\end{abstract}

\section{Keywords}

IUCN, Kosovo, plant conservation, threatened plants

\section{Introduction}

The determination of high priority biodiversity areas and the development of effective conservation measures with a view to saving as many plant taxa as possible are fundamentally key steps in conservation strategies (WARMAN and SinClaIr 2000; Linder, 2001; MillaKu et al., 2017). In this context, the national-based Red lists (based on IUCN International Union for Conservation of Nature - rules and guidelines) remain the most popular tools for their proper identification (VERMEULEN and KozIELl, 2002; MARTIN, 2009). Red lists primary aim is to offer clear and easy un- derstandable quantitative and qualitative estimates of extinction risk in the wild for endangered and endemic taxa (Gärdenfors, 2001; Possingham et al., 2002; Türe and BöcüK, 2010; FLORENTINE et al., 2013). Anyhow, in order to acquire effective conservation assessment, exact quantitative criteria for evaluating the relative degree of exposed threat by taxa are required (Sтомs, 2000). Proper planning in the framework of protected areas by using multi-criteria evaluations that result in creation of accurate biodiversity maps and other valuable outputs are of crucial importance therein (Freitag, et al., 1998; WhitTaker et al., 2005). 
Kosovo represents an important biodiversity centre of Europe with high level of plant diversity and endemism. The entire flora contains 3,000 vascular plant taxa (Stevanović, 1999; 2007; Millaku, 2013), with 9.9\% of them being threatened (Millaku, 2013; Table 1) and over 19\% endemic (REXHEPI, 1982; KRASNIQI, 1998; Stevanović, et al. 2003; Tomović et al., 2014). Their most common threats are unsustainable land management practices, fire, grazing as well as cultivation malpractices. Kosovo's plant diversity is relatively well documented on Grid-System started by STEVANOvić et al. (2007) and additionally by MiLlaKu (2013). Nonetheless, it requires more detailed quantitative evaluation in order to specify sites of conservation priorities. Thus, the aims of the present study are: (i) to specify the distribution patterns of threatened endemic plants based on grid-square system and IUCNbased risk category assigned by the Red Book of Vascular Plants of Kosovo (Millaku 2013), (ii) to determine conservation importance of grid squares using quantitative approach with the numbers of threatened and endemic plant taxa and (iii) to provide information on their phytogeographical origin and taxonomical affiliation at the level of families and genera. This national-based, extensive biodiversity pattern of threatened and endemic vascular plants can then become a spotlight for further comprehensive studies and detailed conservation planning.

Table 1. Distribution of plant taxa according to their risk category in Kosovo (for more details see MillaKu, 2013)

\begin{tabular}{ccc}
\hline Risk category & No. of species & $\%$ \\
\hline EX (extinct) & 1 & 0.03 \\
EW (extinct in the wild) & 1 & 0.03 \\
CR (critically & 61 & 2.03 \\
endangered) & 86 & 2.86 \\
EN (endangered) & 19 & 0.63 \\
VU (vulnerable) & 34 & 1.13 \\
NT (near threatened) & 35 & 1.16 \\
LC (least concern) &
\end{tabular}

\section{Materials and methods}

\section{Study area}

Kosovo is located between $41^{\circ}-43^{\circ}$ north latitude and $20^{\circ}-21^{\circ}$ east longitude in the central part of the Balkan Peninsula (Fig. 1), South-Eastern Europe. It is situated inside of a mountainous ring with a total of $10,908 \mathrm{~km}^{2}$ land area, surrounded by Sharri Mts in the southern part, Kopaonik Mts in the north and Bjeshkët e Nemuna in the south-west. Kosovo belongs to the temperate zone with a typical continental climate being prevalent in the country. The annual average temperature varies between $9.3^{\circ} \mathrm{C}$ and $9.5^{\circ} \mathrm{C}$ and annual rainfall values range from $700 \mathrm{~mm}$ and $900 \mathrm{~mm}$ (ÇAVOLLI, 1997).

\section{Data collection}

Evaluating diversity of endemic and threatened species and their distributional patterns always relies directly on the available databases and particular country information. In Kosovo, ten volumes "Flora of SR Serbia" is a main source of plant diversity up to now (Josifović, 1970-1976, 1977; SARIć and DikLIĆ, 1986). These records were completed by herbarium collections (Herbarium of the Faculty of Mathematics and Natural Sciences of the University of Prishtina) and sources concerning plant species distribution in Kosovo (HAYEK, 1924-1933; TURRILL, 1929; Tutin et al., 1964-1980; ReXhePI, 1986, 1997, 2007; Stevanović et al., 2003, 2007; ReXHEPI et al., 2005, 2009; Amidžıć et al., 2013; Tomović et al., 2003, 2014; MillaKu et al., 2008, 2017) and the Red Book of Vascular Plants of the Republic of Kosovo (Millaku 2013).

In our study, we analyzed articles published up to 2018 and updated information accordingly concerning the threatened plant taxa and the endemics, their risk status and distribution areas by taking into consideration all the available literature sources we could acquire about new records and published checklists for Kosovo (REXHEPI, 1982, 1986; Hundozi, 1983; PAJAZITAJ, 1985; KrasniQI et al., 1990; AMIDŽIĆ and KRIVOŠEJ, 1998; RANĐELOVIĆ et al., 1998; Millaku et al., 2008, 2017, 2018; UKAJ et al., 2012; AmidžIĆ et al., 2013; ANONYMOUs, 2014; Berisha et al., 2014; KRASNIQI et al., 2015a, 2015b).

\section{Analysis}

The Grid System description of the distribution of native vascular plants has proven to be very convenient for floristic and systematic studies alike. Up to now, a large number of studies are being based on this system, therefore, we have chosen the same system for our study due to ease of data manipulation.

Using the traditional list method we initially determined the number of threatened and endemic plants in each grid square $(20 \times 20 \mathrm{~km})$. Each grid square had an assigned number of plant taxa it bears. Later, using the "Ordered Weighted Averaging" (OWA) method, we determined the conservation importance $(\mathrm{CI})$ of each grid. Using this method, we have considered the number of grids in which each taxon is distributed, the threatened and endemic plant number in each grid square and the significance of each risk category - all this followed by assigning appropriate numerical values to each variable according to their importance (VERMEULEN and KOZIELL, 2002).

The risk category values were established as follows:

$\begin{array}{ll}\text { EX (extinct) } & 8 \\ \text { EW (extinct in the wild) } & 7 \\ \text { CR (critically endangered) } & 6 \\ \text { EN (endangered) } & 5 \\ \text { VU (vulnerable) } & 4 \\ \text { NT (near threatened) } & 3 \\ \text { LC (least concern) } & 2 .\end{array}$




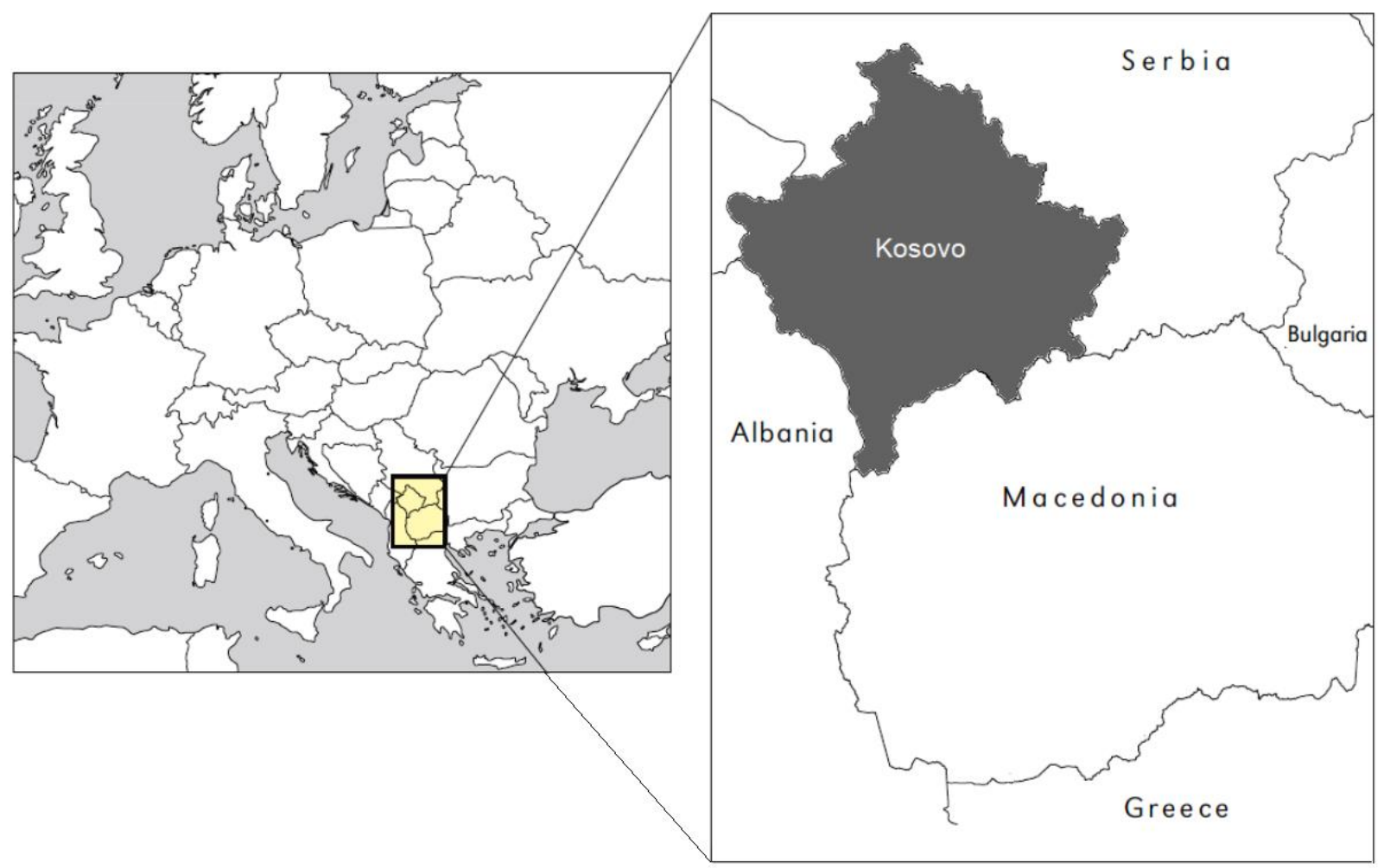

Fig. 1. Location of Kosovo in South-Eastern Europe.

The following variables were applied for each grid square to estimate the Threatened Value (TV):

- the number of threatened and endemic plant taxa $(n)$

- the level of risk category for each threatened and endemic plant taxa $(i)$

- the number of grid squares $(n g)$ in which threatened and endemic plant taxa are naturally distributed.

A logical grouping of assessed taxa was applied while defining the 'Threatened Value', in a sense when a certain taxa with higher threat level and confined distribution argues a higher TV within a grid square(s) than another comparable taxa with lower threat levels, with wider distribution and with lower threat levels.

Our calculation followed formula:

$$
\mathrm{TV}_{\mathrm{D}}=\sum_{\mathrm{i}-1}^{8} \cdot \sum_{\mathrm{ng}=1}^{\mathrm{ti}}(9-\mathrm{i}) \cdot(29-\mathrm{ng}) \cdot \mathrm{n}_{\mathrm{i}, \mathrm{n}}^{\mathrm{D}}
$$

The values have the following meaning:

TV - Threat value;

$\mathrm{D}$ - represents any grid square;

$\mathrm{n}_{\mathrm{i}, \mathrm{ng}}^{\mathrm{D}}$ - represents the threatened plant taxa number in related grid, risk category and grid number;

$\mathrm{i}$ - represents the risk category importance factor;

ng - represents the "number of grid squares" in which threatened and endemic plant taxa naturally occur. The 'Total Threat Value' of all grid squares is

$$
T V_{T}=\sum_{D} T V_{D}
$$

and finally, the Conservation Importance (hereafter CI) for a grid square is:

$$
C I=\frac{T V^{D}}{T V^{T}}
$$

For each grid square, the CI values were estimated and used for the assessments in conservation priority terms. Values range from 0 to 1 and are applied to the whole grid squares. Higher CI values indicate higher conservation importance. After calculating the CI values for each grid square, they were arranged into four main groups as follows:

- "Very high conservation importance" - if CI values of a grid square $>$ the average $\mathrm{CI}(\overline{\mathrm{C} 1})+\alpha$

- "High conservation importance" - if $\overline{\mathrm{C} 1}+\alpha>\mathrm{Cl}$ value of the grid square

- "Average conservation importance" - if $\overline{\mathrm{Cl}}<\mathrm{Cl}$ value of a grid square $<-\alpha$

- "Low conservation importance" - if $\mathrm{Cl}$ value of a grid square $<\overline{\mathrm{C} 1}-\alpha$.

\section{Results}

Threatened plant taxa of seven risk categories were recorded in 33 out of 41 total grid squares in Kosovo. The highest threat values were found for the grid squares C5, D4, E4, G6, G7, G8 and H6. Threatened and endemic plant taxa of CR and EN categories mostly dominated in D4, E4, G7 and G8 grid squares (Table 2), but 60 taxa were represented exclusively in one square. The highest number of endangered and endemic plant species was found in grid squares D4, E4, G7, G8, and H6, although many 
grid squares (C5, C6, D4, D9, E4, E6, E7, F5, F6, F7, F9, G6, G7, G8, G9 and H6) contain at least one plant species evaluated in CR category (Table 3 ).

Most of the recorded taxa originated from South-Eastern Europe (80), followed by Balkan (21) and Mediterranean-Mountain (18), but only a relatively few were associated with phytogeographic regions of Eurimediterranean (9) and Orophyte of SE-Europe (8). There is also 19 stenoendemic species recorded in flora of Kosovo (Table 4).

The grid squares classification on the map of Kosovo is based on their conservation importance, as shown in Figure 5. The grid squares, according to their individual gained CI values (Fig. 2) were split into four respective groups: very high, high, medium and low CI group. Grid squares that reached CI values of $>0.19$ were classified into the very high CI group [D4 (0.4300), G7 (0.3910), G8 (0.2750), E4 (0.2860), H6 (0.2040), G6 (0.2040) and C5 (0.1940)] Grid squares that reached CI values of $>0.03$ were classified into the high CI group [F5 (0.1130), F7 (0.1430), E6 (0.1250), D5 (0.0740), F8 (0.0540), F9 (0.0540), C6 (0.0480), G9 (0.03110), D9 (0.0400), F6 (0.0350), D7 (0.0350), C4 (0.0340) and D8 (0.0310)]. Grid squares that reached $\mathrm{CI}$ values of $>0.001$ were classified into the medium CI group [F4 (0.0260), E7 (0.0250), B8 (0.0150), D6 (0.0150), C7 (0.0140), B7 (0.0130), C8 (0.0100), E9 (0.0100), E10 (0.0100), E8 (0.0090), E5 (0.0060) and H7 $(0.0050)]$. And finally, all grid squares that reached zero CI values were classified into the low $\mathrm{CI}$ group [A6, A7, A8, B6, C9, D7, D8, E11 and F10].

\section{Discussion}

One of the most basic conservation duties relies on the proper identification of high-biodiversity priority areas that are facing or are expected to face biodiversity loss (TROusDALE and GRegory, 2004; ChANG-Le et al., 2007). Each of the world regions has its own biodiversity hotspots and they indicate areas of higher priority for protection regionally or locally (BOUFFORD and VAN DIJK, 1999; ARAÙJO, 2002). While "global hotspots" are those specific areas of the planet that contain $>0.5 \%$ of world plant species (out of $~ 300.000$ ) as endemics and should have experienced a major loss of $>65 \%$ of its primary vegetation (MYERS et al., 2000).

The families and genera with the highest threatened endemics are Asteraceae, Caryophyllaceae, Brassicaceae and Achillea, Viola, Potentilla, respectively (Fig. 3 and Fig. 4). The highest conservation importance (CI) was determined for grid squares situated in the southern and western part of the country, e.g. D4 (0.4300), G7 (0.3910), G8 (0.2750), E4 (0.2860), B7 (0.0699), H6 (0.2040), G6 (0.2040) and C5 (0.1940). On the contrary, the grid squares (A6, A7, $\mathrm{A} 8, \mathrm{~B} 6, \mathrm{C} 9, \mathrm{D} 10, \mathrm{D} 11$ and F10) with the lowest (zero) $\mathrm{CI}$ values following our methodology occur primarily in northern and eastern regions (Fig. 2, 5).

In this context, the ratio of endemic species in Kosovo towards the total global diversity is insignificant and does not meet the criteria of a global hotspot. However, the number of endemics (and sub-endemics) in Kosovo towards its small territory and the approximate number of plant taxa is relatively high (19\% from ca 3,000 plant taxa in total). Kosovo differs from most countries in SE Europe and the Balkans with its rich plant diversity, with dominant mountainous chorological groups and orophytic elements. It ranks high in terms of biodiversity richness among countries of this part of Europe (REXHEPI, 1982; STEVANOvić, 1996; Tomović et al., 2014; GavriLović et al., 2017). This could be explained by heterogenous geological substrates (limestone, silicate and serpentine) accompanied by wide altitudinal range $(297 \mathrm{~m}$ at the shores of the White Drin river up to $2,656 \mathrm{~m}$ at the peak of Gjeravica Mt.), which in turn create distinct vegetation types with unique plant species assemblages. A combination of diverse climatic, edaphic and habitat conditions have facilitated the development and survival of many high-mountain plant taxa that were differentiated during the long and intriguing speciation processes (Stevanović and Stevanović, 1995). Additionally, micro-allopatric speciation (TzEDAKIs et al., 2002) and the period of Ice Age (REXHEPI, 1982) were particularly significant for isolation and the consequent neospeciation processes, during which new infraspecific taxa were created.

Table 2. The grid squares $(n g)$ with occurrence of threatened and endemic plant taxa and their Threat value (tv)

\begin{tabular}{rrrrrrrr}
\hline NG & TV & NG & TV & NG & TV & NG & TV \\
\hline A6 & 0 & C8 & 10 & E4 & 297 & F6 & 40 \\
A7 & 0 & C9 & 0 & E5 & 6 & F7 & 162 \\
A8 & 0 & D4 & 472 & E6 & 151 & F8 & 59 \\
B6 & 0 & D5 & 85 & E7 & 25 & F9 & 54 \\
B7 & 13 & D6 & 15 & E8 & 9 & F10 & 0 \\
B8 & 15 & D7 & 35 & E9 & 10 & G6 & 229 \\
C4 & 34 & D8 & 31 & E10 & 10 & G7 & 443 \\
C5 & 210 & D9 & 51 & E11 & 0 & G8 & 312 \\
C6 & 53 & D10 & 0 & F4 & 26 & G9 & 52 \\
C7 & 14 & D11 & 0 & F5 & 165 & H6 & 246 \\
& & & & & H7 & 5 \\
\hline
\end{tabular}




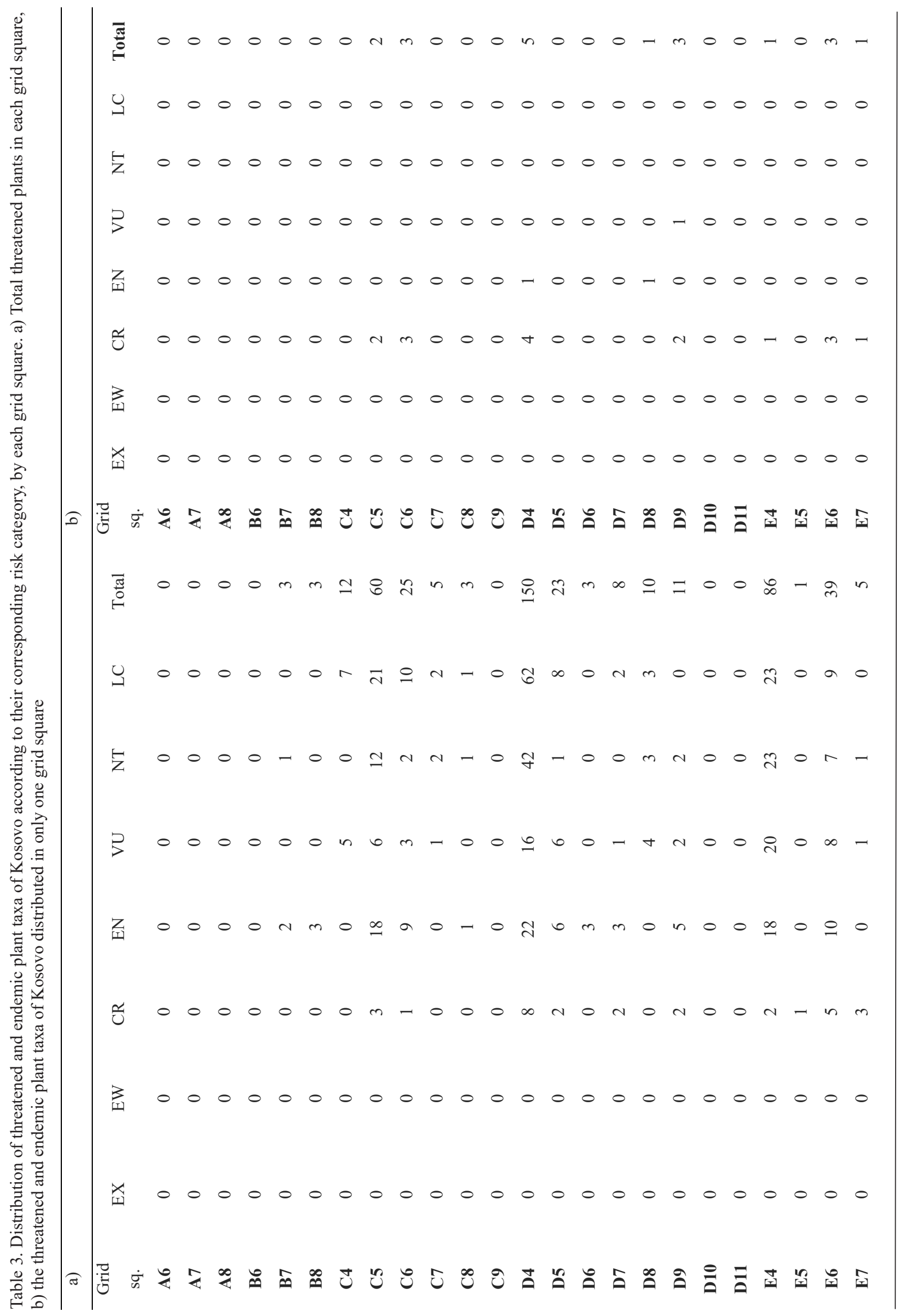




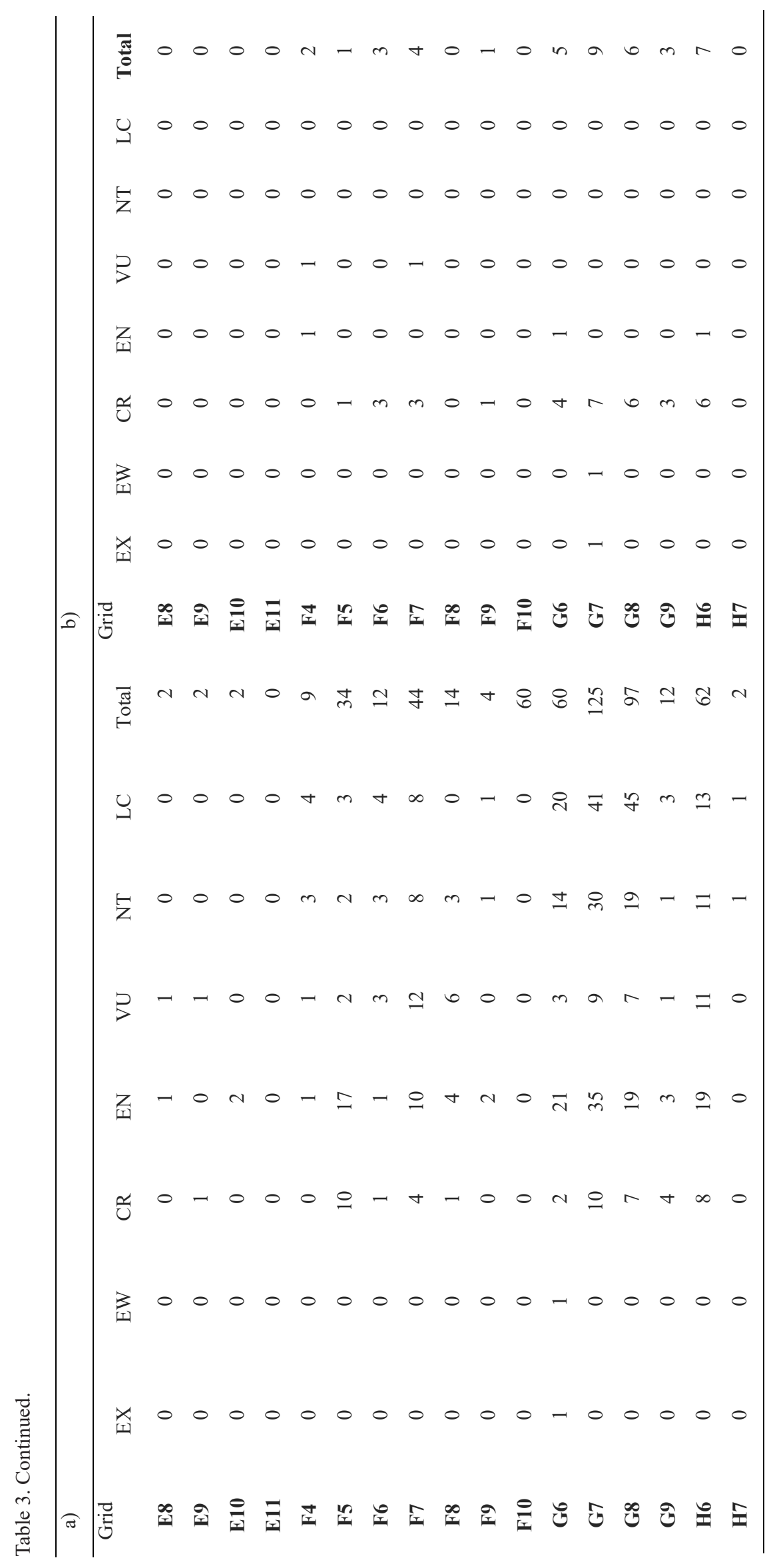


One of the most widely accepted evaluation criteria for threatened and endemic species are IUCN Red lists (VERMEULEN and KOZIELL, 2002; MARTIN, 2009) that are equally used to identify priority biodiversity areas for conservation (SAmwAYs and GRANT, 2007).

On our work, we present two different evaluation methods. The list method includes only the numbers of threatened and endemic plant taxa for each grid square. All these plant taxa are seen as equal to each other concerning their gained values (CAVIERES et al., 2002). The provided information here is rather crude and mostly unsatisfactory including numbers (KeITH, 1998), though they can be useful for certain comparative analysis. The second method (Ordered Weighted Averaging) represents a useful methodology when comparing the conservation merit of plant taxa. This approach is not solely based on threatened endemic and endangered plant taxa numbers for each grid square but also some quantitative values, be it risk category level and distribution characteristics of the given taxa. As a result of this approach, the obtained conservation priorities for the grid squares are different from two methods. This is especially noticeable in grid squares with higher CI values; even in grid squares of the same CI values they seem almost similar to each other. Consequently, this method allows a rather more effective arrangement of grid squares based on their conservation priorities (VERMEULen and Koziell, 2002; Valente and VetTorazZI, 2008).

Several previous studies (e.g., STEBBINS and MAJOR, 1965; MÉDAil and Verlaque, 1997; Wege et al., 2014) pointed out that the highest concentration of endemic taxa are found in floristically rich and diverse regions, with presence of extreme environmental gradients. Based on the same studies, there are indications that along with floristic richness, the isolation (e.g., mountains, rivers) and environmental discontinuities are among the main factors that promote endemism. The highest CI values on our study have gained high mountainous regions that have climatic, geologic and edaphic discontinuities. While lowest CI values were re- corded on beech forests and woodlands of Northern, NorthEastern and Eastern Kosovo.

Remarkable floristic diversity with many endemic species and consequently very high CI values were observed in area (grid squares) of 'Bjeshkët e Nemuna' National Park, including several important mountain ranges (e.g., Zhleb, Gjeravicë, Maja e Strellcit, Pleçe, Koprivnik and Liqenat). Almost equally very high CI values were recorded across the 'Sharri' National Park in the south. This area covers various mountains, such as Vracë, Kobilicë, Luboten, Maja e Zezë, Oshlak, Brod and Koritnik. The high conservation importance was also ascribed to Pashtrik Mt. in the SW Kosovo (grid square F5). There is ongoing initiative from the Ministry of Environment to establish this region as a Natural Park (ANONYMUs, 2018) because its high biodiversity value has been proven several times (REXHEPI, 1982; MiLLAKU, 2013; Millaku et al., 2017; Mustafa et al., 2018).

Table 4. Distribution of phytogeographic origins of threatened and endemic plant taxa in Kosovo

\begin{tabular}{lcc}
\hline Phytogeographic region & $\begin{array}{c}\text { No. of } \\
\text { species }\end{array}$ & $\%$ \\
\hline SE-Europe & 80 & $31 \%$ \\
Balkan & 31 & $12 \%$ \\
Stenoendemic & 21 & $8.0 \%$ \\
Mediterranean Mountain & 19 & $7.5 \%$ \\
Orophyte South-European & 18 & $7.0 \%$ \\
Balkan Anatolia & 16 & $6.2 \%$ \\
Stenomediterranean & 9 & $3.5 \%$ \\
Eurimediterranean & 9 & $3.5 \%$ \\
Orophyte South East & 8 & $3.1 \%$ \\
European & & \\
\hline
\end{tabular}

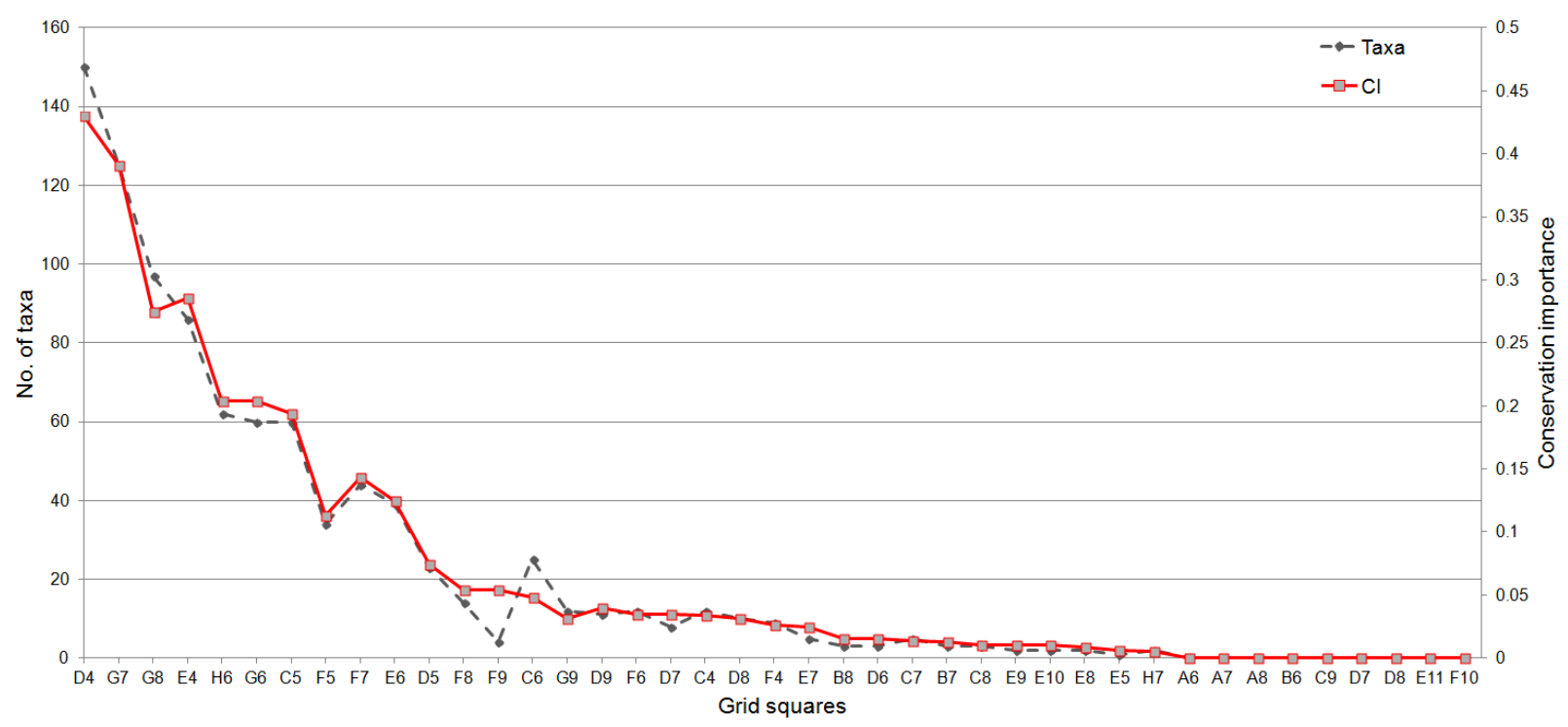

Fig. 2. Calculation of conservation importance (CI) against the number of endemic and threatened plant taxa in each grid square. 


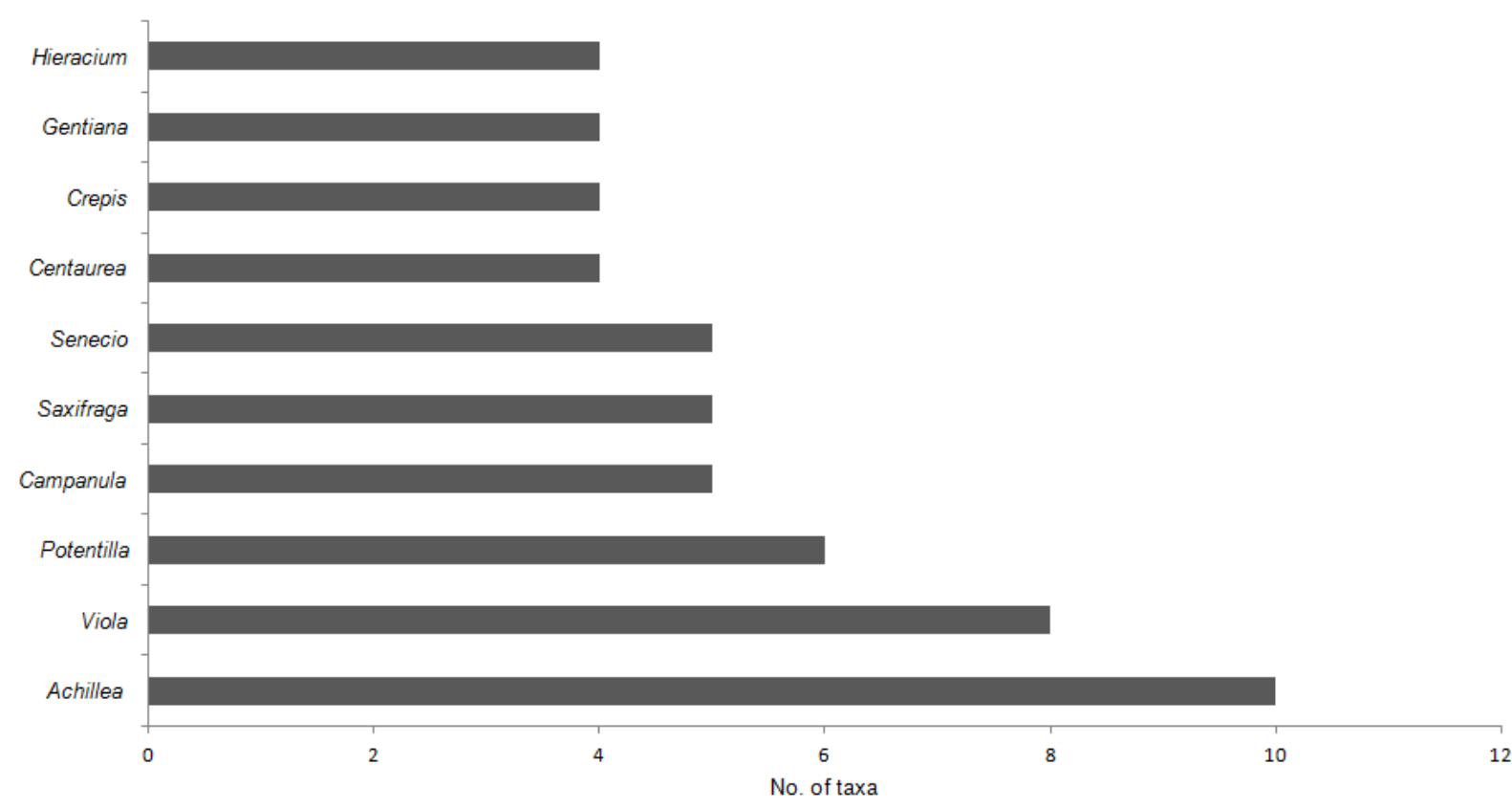

Fig. 3. Genera with the highest number of endemic and endangered plant taxa in Kosovo.

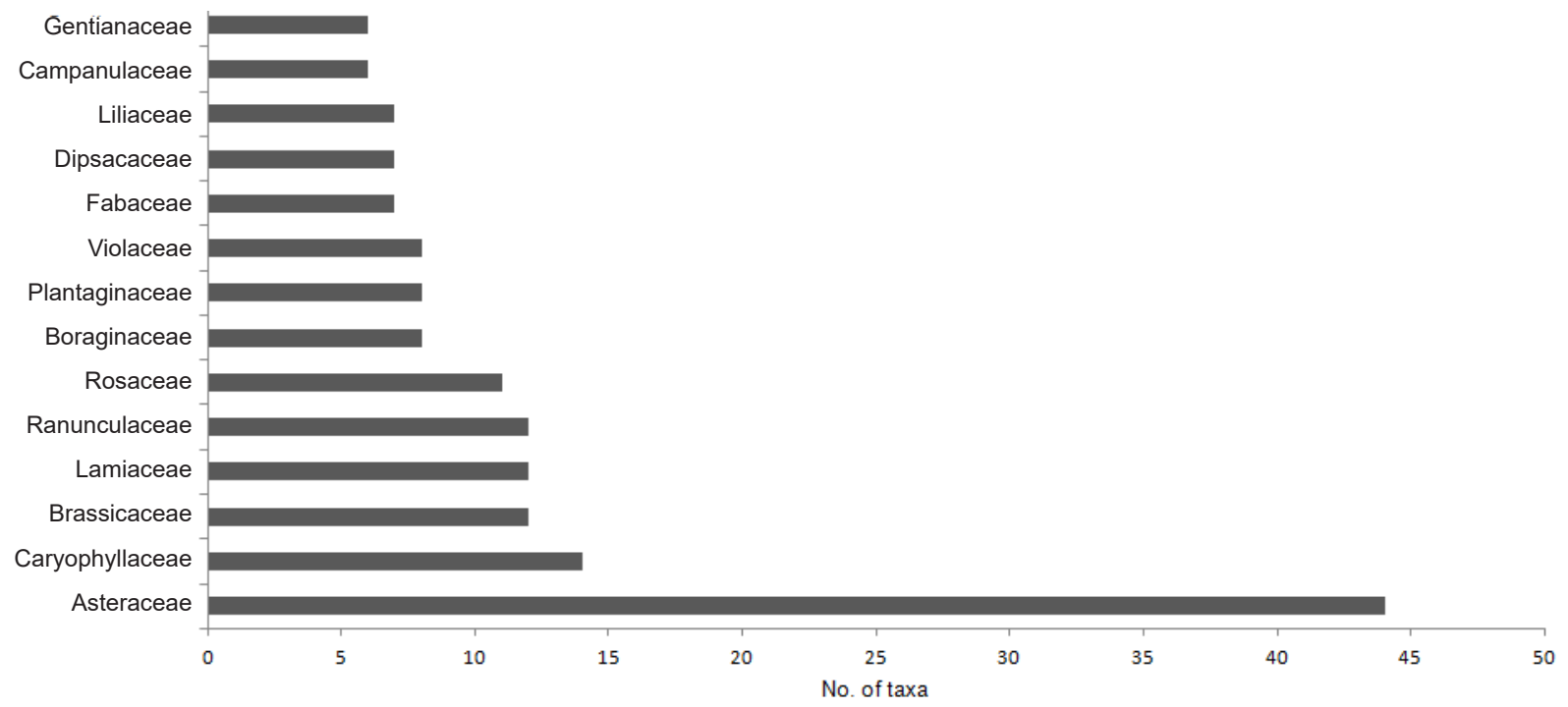

Fig. 4. Families with the highest number of endemic and endangered plant taxa in Kosovo.

One of the most widely accepted evaluation criteria for threatened and endemic species are IUCN Red lists (Vermeulen and Koziell, 2002; Martin, 2009) that are equally used to identify priority biodiversity areas for conservation (SAMwAYS and Grant, 2007).

On our work, we present two different evaluation methods. The list method includes only the numbers of threatened and endemic plant taxa for each grid square. All these plant taxa are seen as equal to each other concerning their gained values (CAVIERES et al., 2002). The provided information here is rather crude and mostly unsatisfactory including numbers (Кегтн, 1998), though they can be useful for certain comparative analysis. The second method (Ordered Weighted Averaging) represents a useful methodology when comparing the conservation merit of plant taxa. This approach is not solely based on threatened endemic and endangered plant taxa numbers for each grid square but also some quantitative values, be it risk category level and distribution characteristics of the given taxa. As a result of this approach, the obtained conservation priorities for the grid squares are different from two methods. This is especially noticeable in grid squares with higher CI values; even in grid squares of the same CI values they seem almost similar to each other. Consequently, this method allows a rather more effective arrangement of grid squares based on their conservation priorities (VERMeulen and Koziell, 2002; Valente and Vettorazzi, 2008). 


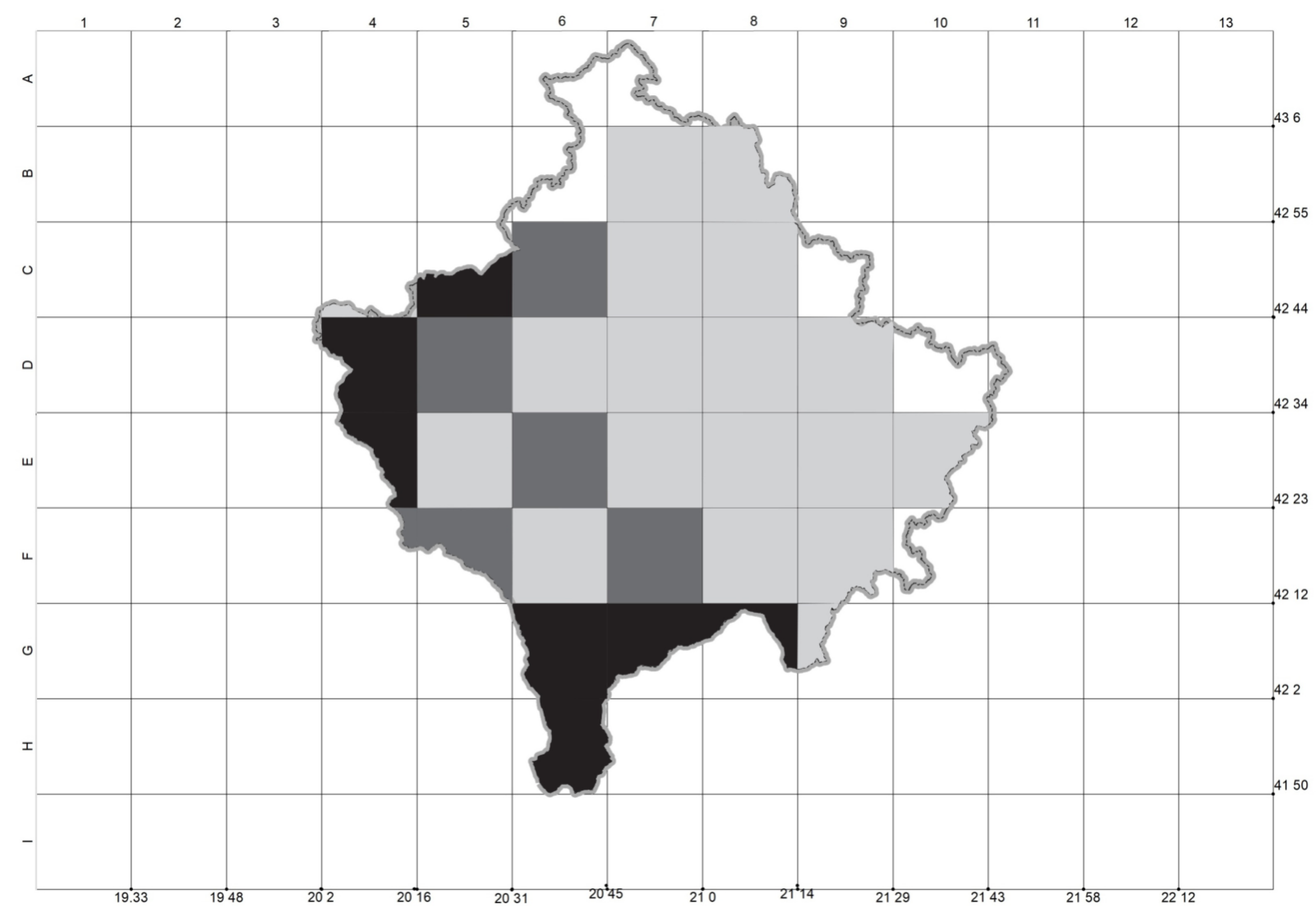

Fig. 5. Map of Kosovo on $20 \times 20 \mathrm{~km}$ grid squares, indicated by their conservation importance $(\mathrm{CI})$ colours. Black (very high $\mathrm{CI}$ ), dark brown (high CI), grey (medium CI) and white (low CI).

Several previous studies (e.g., SteBbins and MAJOR, 1965; Médail and Verlaque, 1997; Wege et al., 2014) pointed out that the highest concentration of endemic taxa are found in floristically rich and diverse regions, with presence of extreme environmental gradients. Based on the same studies, there are indications that along with floristic richness, the isolation (e.g., mountains, rivers) and environmental discontinuities are among the main factors that promote endemism. The highest CI values on our study have gained high mountainous regions that have climatic, geologic and edaphic discontinuities. While lowest CI values were recorded on beech forests and woodlands of Northern, North-Eastern and Eastern Kosovo.

Remarkable floristic diversity with many endemic species and consequently very high CI values were observed in area (grid squares) of 'Bjeshkët e Nemuna' National Park, including several important mountain ranges (e.g., Zhleb, Gjeravicë, Maja e Strellcit, Pleçe, Koprivnik and Liqenat). Almost equally very high CI values were recorded across the 'Sharri' National Park in the south. This area covers various mountains, such as Vracë, Kobilicë, Luboten, Maja e Zezë, Oshlak, Brod and Koritnik. The high conservation importance was also ascribed to Pashtrik Mt. in the SW Kosovo (grid square F5). There is ongoing initiative from the Ministry of Environment to establish this region as a Natural Park (ANONYMus, 2018) because its high biodiversity value has been proven several times
(Rexhepi, 1982; Millaku, 2013; Millaku et al., 2017; Mustafa et al., 2018).

\section{Conclusions}

Environment protection of Kosovo, monitoring and conservation authorities' objectives lie in carefully analyzing and determining areas that provide the most important ecosystems and habitats for biodiversity conservation. The exact depiction of maximum biodiversity in protected areas has become recently a key issue of conservation biology in order to avoid any further and potentially nonrepairable losses on biodiversity. Plant diversity research and distribution patterns at the national level are very important steps to identify the priority areas for biodiversity conservation. Our results can serve as a practical guide for scientific experts and state officials alike that are involved and concerned with conservation issues and related decision making measures in Kosovo.

\section{Acknowledgements}

The authors would like to thank Dr. Ferim Gashi (Department of Geography, University of Prishtina) for his helpful assistance with the maps. We would like to express our 
very great appreciation to Dr. Ferat Rexhepi (Department of Biology, University of Prishtina) for his valuable and constructive suggestions during the planning and development of this research work. The authors would also like to thank the reviewers for all of their careful, constructive and insightful comments.

\section{References}

AmidžIĆ, L., KRIVOŠEJ, Z., 1998. High-mountain flora of Nedzinat and Zuti Kamen (Prokletije Mts.). University Thought, 1 (1): 99-112.

Amidžić, L., Panjković, B., Perić, R., 2013. Chorological analysis of the endemic flora in the Metohijan Prokletije Mountains. Archives of Biological Science, Belgrade, 65 (2): 645-650.

ANONYMous, 2014. Red list of vascular flora of the Republic of Kosovo. Prishtina: MESP - KEPA, p. 1- 8.

ANONYMOUS, 2018. Professional rationale for taking under protection the Mt. Pashtrik and Vërmica lake in the Natural Park / Transboundary Protected Area. Prishtina: MESP, p. 1-36.

Araùjo, M.B., 2002. Biodiversity hotspots and zones of ecological transition. Conservation Biology, 16: 1662-1663.

Berisha, N., Millaku, F., Krasnigi, E., Gashi, B., 2014. Rare and endangered geophyte plant species in serpentine of Kosovo. Ecologia Balkanica, 6 (2): 67-74.

BoufFord, D.E., VAN DiJK, P.P., 1999. South-central China. In Mittermeier, R.A., Myers, N., Mittermeier, C.G. (eds). Hotspots: Earth's biologically richest and most endangered terrestrial ecoregions. Mexico City: Cemex, p. 339-350.

Cavieres, L.A., Arroyo, M.T., Posadas, P., Marticorena, C., Matthei, O., Rodríguez, R., Squeo, F.A., Arancio, G., 2002. Identification of priority areas for conservation in an arid zone: application of parsimony analysis of endemicity in the vascular flora of the Antofagasta region, northern Chile. Biodiversity and Conservation, 11 (7): 1301-1311. doi: 10.1023/a:1016001714358

ÇAVOLLI, R., 1997. Gjeografia regjionale e Kosovës [Regional geography of Kosovo]. Prishtina: EMMK. 41 p.

Chang-Le, M., Moseley, R.K., Wen-Yun, C., Zhe-Kun, Z., 2007. Plant diversity and priority conservation areas of north western Yunnan, China. Biodiversity and Conservation, 16: 757-774. doi: 10.1007/s10531-005-6199-6

Florentine, S.K., Gardner, J., Graz, F.P., Moloney, S., 2013. Plant recruitment and survival as indicators of ecological restoration success in abandoned pasture land in Nurcoung, Victoria, Australia. Ecological Processes, 2 (1): 34. doi:10.1186/2192-1709-2-34

Freitag, S., Nicholls, A.O., Van JaArseveld, A.S., 1998. Dealing with established reserve networks and incomplete distribution data sets in conservation planning. South African Journal of Science, 94: 79-86.

GärdENFORs, U., 2001. Classifying threatened species at national versus global levels. Trends in Ecology \& Evolution, 16 (9): 511-516. https://doi.org/10.1016/s01695347(01)02214-5

Gavrilović, B., Tomović, G., Niketić, M., Milenković, M., Simić, S., Radovanović, M., 2017. Geoecological characteristics of plant endemism in the Balkan part of Serbia. Botanica Serbica, 41 (2): 177-197.
HAYeK, A., 1924-1927. Prodromus florae peninsulae Balcanicae. 1. Band, Pteridophyta, Gymnospermae, Dicotyledoneae (Apetalae et Choripetalae). Dahlem bei Berlin: Verlag des Repertoriums. $1193 \mathrm{p}$.

HayeK, A., 1928-1931. Prodromus florae peninsulae Balcanicae. 2. Band, Dicotyledoneae Sympetalae. Dahlem bei Berlin: Verlag des Repertoriums. $1152 \mathrm{p}$.

Hayek, A., 1932-1933. Prodromus florae peninsulae Balcanicae. 3. Band, Monocotyledoneae. Dahlem bei Berlin: Verlag des Repertoriums. 472 p.

Hundozi, B., 1983. Flora of low meadows of Kosovo. Proceedings of the Faculty of Natural Sciences. FNS - University of Prishtina, 9 (1): 235-251.

Josifović, M. (ed.), 1970-1976. Flora SR Srbije 1-8 [Flora of Serbia 1-8]. Beograd: Srpska akademija nauka i umetnosti. $5417 \mathrm{p}$.

Josifović, M. (ed.), 1977. Flora SR Srbije 9, dodatak [Flora of Serbia - supplement]. Beograd: Srpska akademija nauka i umetnosti. $257 \mathrm{p}$.

Kerth, D.A., 1998. An evaluation and modification of World Conservation Union Red list criteria for classification of extinction risk in vascular plants. Conservation Biology, 12 (5): 1076-1090. doi: 10.1046/j.15231739.1998.97202.x

Krasniqi, E., Beqolli-Gashi, A., ReXhepi, F., 2015a. Vascular flora of Badove with its surroundings. International Journal of Ecosystems and Ecology Science, 5 (4): 575580.

Krasniqi, E., Millaku, F., Thaqi, L., Avdiu, A., Krasniqi, H., 2015b. Vascular flora of the Carralluka meadows, Kosovo. International Journal of Ecosystems and Ecology Science, 5 (4): 581-586.

KRASNIQI, F., 1998. The features of Kosovo's flora and vegetation and the problem of their protection. Research, 6. Prishtina: Kosovos Academy of Sciences and Arts, p. $51-66$.

Krasniqi, F., Hundozi, B., Pajazitaj, Q., 1990. A short contribution to the flora of Kosovo. Razprave - SAZU, Ljubljana, 29 (6): 97-104.

LINDER, H.P., 2001. Plant diversity and endemism in sub-Saharan tropical Africa. Journal of Biogeography, 28: 168182. https://doi.org/10.1046/j.1365-2699.2001.00527.x

Martin, J.L., 2009. Are the IUCN standard home-range thresholds for species a good indicator to prioritise conservation urgency in small islands? A case study in the Canary islands (Spain). Journal for Nature Conservation, 17 (2): 87-98.

MéDail, F., Verlaque, R., 1997. Ecological characteristics and rarity of endemic plants from southeast France and Corsica: implications for biodiversity conservation. Biological Conservation, 80 (3): 269-281. https://doi. org/10.1016/s0006-3207(96)00055-9

Millaku, F., Elezaj, I., Berisha, N., 2018. Sympatric area and ecology of some Tulipa species in the West Balkan Peninsula. Thaiszia Journal of Botany, 28 (1): 35-47.

Millaku, F., Heiselmayer, P., Rexhepi, F., Krasnigi, E., Eichberger, Ch, Haziri, A., 2008. Endemic, stenoendemic and relic plants in serpentines of Kosovo. Sauteria, 16: $149-161$.

Millaku, F., Krasniqi, E., Berisha, N., ReXhepi, F., 2017. Conservation assessment of the endemic plants from Kosovo. Hacquetia, 16 (1): 35-47. doi:10.1515/hacq2016-0024 
Millaku, F., Rexhepi, F., Krasniqi, E., Pajazitaj, Q., Mala, Xh., BERISHA, N., 2013. The Red book of vascular flora of the Republic of Kosovo. Prishtina: MESP. $436 \mathrm{p}$.

Mustafa, B., Hajdari, A., Mustafa, V., Pulaj, B., 2018. Natural heritage in the Republic of Kosovo: looking for potential UNESCO sites. Landscape Online, 63: 1-16.

Myers, N., Mittermeier, R.A., MitTermeier, C.G., DA FonsecA, G.A.B., Kent, J., 2000. Biodiversity hotspots for conservation priorities. Nature, 403: 853-858. doi:10.1038/35002501

Pajazitaj, Q., 1985. Contribution to the knowledge on the ruderal flora of Kosovo. Nature of Kosova, 1 (1): 69-74.

Possingham, H.P., Andelman, S.J., Burgman, M.A., Medellín, R.A., Master, L.L., Keith, D.A., 2002. Limits to the use of threatened species lists. Trends in Ecology \& Evolution, 17 (11): 503-507. https://doi.org/10.1016/ s0169-5347(02)02614-9

RanĐelović, V., Zlatković, B., Amidžıć, L., 1998. Flora and vegetation of high-mountain peat bogs of Sharri Mountains. University Thought, 5 (1): 91-98.

RexhepI, F., 1982. Balkan endemics in the high-mountian flora of Kosovo. Scientific Research Bulletin of FNS, 8: 211-219.

RexhePI, F., 1986. High mountain flora of Kosovo. Prishtina: FNMS, University of Prishtina. 349 p.

RexhePI, F., 1997. Mediterranean, Submediterranean and Illyric floristic elements in the flora of Kosovo. Bocconea, 5 (2): 451-456.

ReXhePI, F., 2007. Vegetation of Kosovo (I). Prishtina: FNMS, University of Prishtina. $345 \mathrm{p}$.

Rexhepi, F., Millaku, F., Krasniqi, E., 2005. Endemic plant species and vegetation with endemic character in "Sharri" National Park, Kosovo. In XVII International Botanical Congress, 12-16 July 2005. Book of Proceedings. Vienna, Austria, p. 611-620.

Rexhepi, F., Millaku, F., Krasnigi, E., 2009. Some species of Medierranean floristic element in the Albanian Alps of Kosovo. Bocconea, 23 (1): 5-11.

Samways, M. Grant, P., 2007. Honing red list assesment of lesser-known taxa in biodiversity hotspots. Biodiversity and Conservation, 16: 2575-2586.

SARIĆ, M., DikLIĆ, N. (eds), 1986. Flora SR Srbije 10. Dodatak (2) [Flora of Serbia 10 - supplement (2)]. Srpska akademija nauka i umetnosti, Beograd. 401 p.

Stebbins, G. L. Major, J., 1965. Endemism and speciation in the Californian flora. Ecological Monographs, 35: 1-35.

Stevanović, V., 1996. Analysis of the Central European and Mediterranean orophytic element on the mountain of the W. and Central Balkan Peninsula, with special reference to endemics. Bocconea, 5: 77-97.

Stevanović, V. (ed), 1999. The Red Data book of the flora of Serbia 1. Extinct and critically endangered taxa. Belgrade: Ministry of Environment of the Republic of Serbia, Faculty of Biology, University of Belgrade, Institute for Protection of Nature of the Republic of Serbia. 566 p.

Stevanović, V., Jovanović, S., Lakušić, D., Niketić, M., 1999. Characteristics of the flora of Serbia and its phytogeographical division. In Stevanović, V. (ed). The Red data book of the flora of Serbia 1. Extinct and critically endangered taxa. Belgrade: Ministry of Environment of the Republic of Serbia, Faculty of Biology, University of Belgrade, Institute for Protection of Nature of the Republic of Serbia, p. 393-399.
Stevanović, V., Stevanović, B., 1995. Osnovni klimatski, geološki i pedološki činioci biodiverziteta kopnenih ekosistema Jugoslavije [Basic climatic, geological and pedological factors of biodiversity of terrestrial ecosystems of Yugoslavia]. In Stevanović, V., VAsić, V. (eds). Biodiverzitet Jugoslavije sa pregledom vrsta od međunarodnog znaćaja. Belgrade: Ecolibri, Biološki fakultet, p. 75-95.

Stevanović, V., Tan, K., IATrou, G., 2003. Distribution of the endemic Balkan flora on serpentine I. Obligate serpentine endemics. Plant Systematics and Evolution, 242 (1-4): 149-170. https://doi.org/10.1007/s00606-003-0044-8

Stevanović, V., Tan, K., Petrova, A., 2007. Mapping the endemic flora of the Balkans a progress report. Bocconea, 21: 131-137.

Stoms, D.M., 2000. GAP management status and regional indicators of threats to biodiversity. Landscape Ecology, 15: 21-33. https://doi.org/10.1023/a:1008105026956

Tomović, G., Niketić, M., Lakušić, D., RanĐelović, V., Stevanović, V., 2014. Balkan endemic plants in Central Serbia and Kosovo regions: distribution patterns, ecological characteristics, and centres of diversity. Botanical Journal of the Linnean Society, 176 (2): 173-202. https:// doi.org/10.1111/boj.12197

Tomović, G., RanĐelović, V., Niketić, M., Vukojičić, S., ZLATKović, B., 2003. New distribution data of some pontic and submediterranean plant species in Serbia. Archives of Biological Science, Belgrade, 55 (1-2): 45-54.

Trousdale, W., Gregory, R., 2004. Property evaluation and biodiversity conservation decision support for making hard choices. Ecological Economics, 48: 279-291. https://doi.org/ 10.1016/j.ecolecon.2003.09.011

TÜRE, C., BöCÜK, H., 2010. Distribution patterns of threatened endemic plants in Turkey: a quantitative approach for conservation. Journal for Nature Conservation, 18 (4): 296-303. https://doi.org/10.1016/j.jnc.2010.01.002

TurriLl, W.B., 1929. The plant-life of the Balkan Peninsula. A phytogeographical study. Oxford: Clarendon Press. xxiii, $490 \mathrm{p}$.

Tutin, T.G., Burges, N.A., Valentine, D.H., Walters, S.M., WeB, D.A. (eds), 1964-1980. Flora Europaea, 1-5. Cambridge: Cambridge University Press. 2246 p.

Tzedakis, P.C., Lawson, I.T., Frogley, M.R., Hewitt, G.M., Preece, R.C., 2002. Buffered tree population changes in a Quaternary refugium: evolutionary implications. Science, 297: 2044-2047.

Ukaj, Sh., Millaku, F., Krasniqi, E., Rexhepi, F., Shala, A., 2012. Magnoliatae (Dicotyledones) without Asteraceae on the Studenica Peak - Kosovo. International Journal of Ecosystems and Ecology Science, 2 (3): 181-186.

Valente, R.D.O.A., Vettorazzi, C.A., 2008. Definition of priority areas for forest conservation through the ordered weighted averaging method. Forest Ecology and Management, 256 (6): 1408-1417. https://doi.org/10.1016/j. foreco.2008.07.006

Vermeulen, S., Koziell, I., 2002. Integrating global and local values: a review of biodiversity assessment. London, UK: International Institute for Environment and Development. $104 \mathrm{p}$.

Warman, L., Sinclair, A., 2000. A systematic method for identifying priority conservation areas using wildlife habitat relationships and observed locations of rare species. In Hollstedt, C., Sutherland, K., InNes, T. (eds). 
From science to management and back: a science forum for southern interior ecosystems of British Columbia. Kamloops, BC: Southern Interior Forest Extension and Research Partnership, p. 141-144.

Wege, J.A., Thiele, K.R., Shepherd, K.A., Butcher, R., Macfarlane, T.D., Coates, D.J., 2014. Strategic taxonomy in a biodiverse landscape: a novel approach to maximizing conservation outcomes for rare and poorly known flora. Biodiversity and Conservation, 24 (1): $17-$ 32. https://doi.org/ 10.1007/s10531-014-0785-4

Whittaker, R.J., AraúJo, M.B., Jepson, P., LAdLe, R.J., WatSON, J.E., WiLlis, K.J., 2005. Conservation biogeography: assessment and prospect. Diversity and Distributions, 11 (1): 3-23. doi:10.1111/j.1366-9516.2005.00143.x

Received December 6, 2019 Accepted March 29, 2020 